\title{
Development of Tasks with Art Elements for Teaching Engineers in English for Specific Purposes Classroom
}

\author{
https://doi.org/10.3991/ijet.v14i23.11955 \\ Nataliia Saienko, Yuliia Olizko ${ }^{(\bowtie)}$ \\ National Technical University of Ukraine, Kyiv, Ukraine \\ juliukrainekyiv@gmail.com \\ Muhammad Arshad \\ The University of Lahore, Lahore-Punjab, Pakistan
}

\begin{abstract}
This article defines the modern interdisciplinary trends in engineering and the collaboration of engineering with other sciences. Science, Technology, Engineering, Arts (STEAM) approach has been chosen as suitable for teaching engineers in English for Specific Purposes (ESP) classroom. The authors created different tasks with art elements in teaching ESP. The topics of the tasks are: material properties, environmental/global sustainability issues, human factors engineering, employment of engineers, and engineering education. Scaffolding, appropriate time management, cooperation, creative atmosphere, native materials are the conditions for the effective usage of the tasks within STEAM approach. The results of the pedagogical experiment in 2019 at the National Technical University of Ukraine "Igor Sikorsky Kyiv Polytechnic Institute" (Igor Sikorsky KPI) amongst 30 chemical engineers proved the improvement of language skills and other skills of the 21 century such as cooperation, digital, problem-solving, creative thinking. An anonymous questionnaire confirmed students' positive perception of the STEAM approach.
\end{abstract}

Keywords-Art, Task, English for specific purposes (ESP), Engineer, Interdisciplinary.

\section{Introduction}

First of all, engineering contexts are becoming more and more multidisciplinary, causing a great deal of change in modern technical education. One innovation that has addressed this trend was developed in 2001 at the National Science Foundation in the United States, for the integration of Science, Technology, Engineering, and, Mathematics (STEM). STEM is based on natural connections between disciplines. "Translations" through these four disciplines can allow students to have increased opportunities for their exploration and problem-solving strategies that can reap additional benefits within many other curriculum areas $[1,5]$. Effective STEM learning includes realworld and authentic problems, involving new and emergent technology, science practices, argument-based practices, and multimodal communication [2]. STEM literacy is 
a broad concept composed of skills, abilities, factual knowledge, procedures, concepts, and metacognitive capacities to gain further learning [3, 12]. The requirements for STEM learning and language learning can sometimes coincide, as both require understanding, listening, speaking, writing, reading skills, and the ability to learn, etc.

The National Institute for Mathematical and Biological Synthesis (NIMBioS) suggests that a good deal of disciplinary collaborations will have a lasting influence on scientific culture [4]. From the data given by the Institute, it is possible to analyse collaborations between engineering and other research areas. The highest number of collaborations are between engineering and biological/biomedical sciences, second place was with health sciences; other collaborations were also noticed between engineering and geological and earth sciences, agriculture and natural sciences, social sciences, humanities, and ocean/marine sciences.

Moreover, based on bibliometric data from the Web of Science, engineering was found to be one of the key fields of interdisciplinary collaborations together with computer science, business, and economics [5]. As it was shown in the data for the period 2004-2015, engineering had the strongest collaborations with computer science, telecommunications, materials science, business and economics, social sciences, public, environmental and occupational health, radiology, nuclear medicine, optics, automation and control systems, mathematics, energy and fuels, and mechanics.

Some engineers are employed in STEM roles in non-STEM sectors, others are in non-STEM roles, but recruited because of their STEM background $[6,10]$. The demand for a strong STEM workforce continues to grow and STEAM helps to recruit, train, and retain such a workforce in ways that are effective and sustainable and foster innovation [7]. To conclude, the scale of engineering is far beyond the technical area and has had an impact on many other sciences.

Currently, more and more universities are focusing on STEM education. Among them are, Massachusetts Institute of Technology, California Institute of Technology, John Hopkins University, EMBRY-RIDDLE Aeronautical University. The Royal Academy of Engineering has identified over 600 organizations involved in supporting STEM engineering education [6].

Later, other disciplines joined STEM, some examples which are of interest to ESP teachers are:

a) Environmental STEM [8]

b) STEMS-2 (Science, Technology, Engineering, Mathematics, Social Sciences and Sense of Place); integrates STEM with social sciences [9]

c) BTEM (Biology, Technology, Engineering, Mathematics) [10] which also requires coordination of knowledge and skills. According to the authors, the interdisciplinary BTEM approach is a good alternative to out-dated methods in teaching when teachers merely convey scientific facts in a rote fashion that have to be memorized to pass examinations

d) STEAM (Science, Technology, Engineering, Arts, and Mathematics) [11], [12]. At first STEAM was successfully used for secondary education in the USA [13], [14], [15], [16], [17], [18], [19], in Korea [20], and Indonesia [21]. Now some scientists try to adopt STEAM for broader educational context at the tertiary level [22], for 
engineering education [23], [24]. Art activities are used for teaching a scienceinfused English course [25]; English as a foreign language classroom [26]. We agree that STEAM is an effective novel approach that can help engineers acquire 21 st-century skills because it includes all advantages of STEM and can offer even more of them.

STEAM is chosen as a targeted approach due to numerous advantages art offers for ESP. For example, art strengthens critical and creative thinking. Creative abilities form an integral part of an innovative productive professional activity [27]. In addition, art allows to be focused, and reduces stress. Additional benefits of art elements in language education were ealier described in our previous research [28]. By art, we mean any form which can be beneficially used for ESP. Art can include performing arts, visual arts, design works, and others. To implement STEAM in the classroom special tasks combining science with art elements should be created and analysed.

\section{Purpose}

The aims of the article are:

a) To choose the approach relevant to ESP goals

b) To develop a set of tasks which can be used to implement STEAM in the classroom.

\section{$3 \quad$ Methodology}

A critical examination was made of the literature related to engineering science nowadays, analysis of ESP syllabus topics and topics of ESP course books for engineers, to define common topics and develop STEAM tasks; analysing, planning and structuring STEAM tasks. Analysis of ESP syllabus topics and topics of ESP coursebooks helped to identify five topics common for different engineering specialisations. They include: material properties, environmental and global sustainability issues, human factors engineering, employment of engineers, engineering education.

Pedagogical experiment was conducted at Igor Sikorsky KPI. 30 chemical engineers of the faculty of Chemical technology used the STEAM tasks in the ESP classroom in spring 2019. Questionnaires were used to determine the 30 students' attitude to STEAM approach. Data were analyzed in the form of percentages. The returning rate of questionnaires was $100 \%$.

\section{Results}

For each chosen topic, a STEAM task that matches STEAM with language objectives was prepared. They can supplement the regular coursework of engineering faculties as they cover general engineering topics. Each of the task focuses on particular 
skills. For example, task 1 primarily focuses on research skills; task 2 is first of all aimed at environmental literacy; 3 focuses on health and safety literacy; 4 encourages students to improve collaboration skills; 5 focuses on cultural literacy.

All STEAM components are integrated into the tasks (Table 1). Science is used to explain some scientific concepts relevant to the topic, technology is used to improve digital skills, engineering explains the techniques used by students to complete a particular task or by scientists to create innovations, art helps to combine all STEAM elements in a creative way, mathematics is used either for calculations, formulas, measurements or to analyze art (symmetry, geometry, proportions).

Table 1. STEAM tasks in ESP classroom

\begin{tabular}{|c|c|c|c|c|c|c|}
\hline & Science & Technology & Engineering & Art & Mathematics & ESP \\
\hline Task 1 & $\begin{array}{l}\text { Materials } \\
\text { science }\end{array}$ & $\begin{array}{l}\text { Using lab or } \\
\text { kitchen devices; } \\
\text { mobile applica- } \\
\text { tions }\end{array}$ & $\begin{array}{l}\text { Testing charac- } \\
\text { teristics of } \\
\text { materials }\end{array}$ & $\begin{array}{l}\text { Preparing a } \\
\text { poster; drawing } \\
\text { pictures; de- } \\
\text { scribing materi- } \\
\text { als of statues }\end{array}$ & $\begin{array}{l}\text { Working with } \\
\text { numbers; US } \\
\text { measurements; } \\
\text { reading formu- } \\
\text { las; saying } \\
\text { calculations; } \\
\text { laws }\end{array}$ & \multirow{5}{*}{$\begin{array}{l}\text { Development of } \\
\text { communicative, } \\
\text { intercultural } \\
\text { and profession- } \\
\text { al competence }\end{array}$} \\
\hline Task 2 & $\begin{array}{l}\text { Sustaina-bility; } \\
\text { Robotics }\end{array}$ & $\begin{array}{l}\text { Robot technol- } \\
\text { ogies; computer } \\
\text { or mobile } \\
\text { phone }\end{array}$ & $\begin{array}{l}\text { Understanding } \\
\text { the process of } \\
\text { robot designing }\end{array}$ & $\begin{array}{l}\text { Making recy- } \\
\text { cled robots; } \\
\text { visiting online } \\
\text { robot exhibition } \\
\text { and real muse- } \\
\text { ums }\end{array}$ & $\begin{array}{l}\text { Working with } \\
\text { numbers, } \\
\text { formulas, } \\
\text { shapes, meas- } \\
\text { urements }\end{array}$ & \\
\hline Task 3 & Ergono-mics & $\begin{array}{l}\text { Safety technol- } \\
\text { ogies; mobile or } \\
\text { computer } \\
\text { applications }\end{array}$ & $\begin{array}{l}\text { Checking the } \\
\text { safety of the } \\
\text { building }\end{array}$ & Writing a poem & $\begin{array}{l}\text { Measuring } \\
\text { workplace } \\
\text { safety parame- } \\
\text { ters; mounting } \\
\text { heights; meas- } \\
\text { urements } \\
\end{array}$ & \\
\hline Task 4 & $\begin{array}{l}\text { Social science; } \\
\text { different } \\
\text { branches of } \\
\text { engine-ering }\end{array}$ & $\begin{array}{l}\text { Technologies } \\
\text { for making } \\
\text { videos }\end{array}$ & $\begin{array}{l}\text { Understanding } \\
\text { the process of } \\
\text { engineering CV } \\
\text { writing and } \\
\text { engineering } \\
\text { companies } \\
\text { foundation }\end{array}$ & $\begin{array}{l}\text { Performing art } \\
\text { (drama, role- } \\
\text { playing) }\end{array}$ & $\begin{array}{l}\text { Working with } \\
\text { statistics }\end{array}$ & \\
\hline Task 5 & Education & $\begin{array}{l}\text { Ranking sys- } \\
\text { tems }\end{array}$ & $\begin{array}{l}\text { Engineering } \\
\text { universities, } \\
\text { description of } \\
\text { exhibited } \\
\text { campus vehi- } \\
\text { cles }\end{array}$ & $\begin{array}{l}\text { Working with } \\
\text { maps; describ- } \\
\text { ing architecture, } \\
\text { art spaces }\end{array}$ & $\begin{array}{l}\text { Working with } \\
\text { indicators, } \\
\text { percentages, } \\
\text { shapes }\end{array}$ & \\
\hline
\end{tabular}

Task 1. Material properties

Aim: Understanding material properties; materials characteristics; measurements.

Creative skills: Critical and creative thinking, imagination skills.

ESP skills: Listening, speaking, reading, writing, translating about properties of different materials

Functional language: Researching, comparing, reasoning, analysing.

Instructions 
a) Collect and bring into the class several examples of materials. Here are some examples: metal, plastic, cotton, glass, grass, branches, corn, leaves, water, stone.

b) Put all the materials brought on the table, look at them. Work in mini-groups. Prepare a list of physical and mechanical properties of the materials or adjectives describing them. Here are some examples: tough, ductile, elastic, stiff, malleable, brittle, bumpy, slippery, stretchy. The group with the biggest number of accurate words wins!

c) In mini-groups prepare a big poster. Use the offline dictionary mobile application to write English explanations for the properties of the materials and draw pictures to illustrate the properties of some of them.

d) Act out to present your poster. Students from other groups raise the hand with the material(s) you talk about and ask questions, agree or disagree. They get a point for the correct demonstration.

e) In groups think of the test/experiment you can do to demonstrate a property of the material. You can do it at home or in the lab. If you experiment out of the class, make a video commenting on all your actions in English.

f) Do you know which materials are used for famous monuments? Think of the materials The Statue of Liberty and the Motherland statue are made of and their properties. Express your ideas. Find out more information about these monuments including numerical information, shape, compare the height of The Statue of Liberty and the Motherland statue in Kyiv. Use the handouts given and a calculator to convert meters to feet and inches.

Task 2. Sustainable future

Aim: Understandingenvironmental issues, robotics.

Creative skills: Critical and creative thinking, imagination skills, personal expression.

ESP skills: Listening, speaking, reading, writing aboutecological issues and new technologies.

Functional language: Summarizing, researching, comparing, reasoning. Instructions

a) In mini-group create a robot using recycled materials. Explain what materials you used. How much does it take for each material to decompose? (Figure 1). 

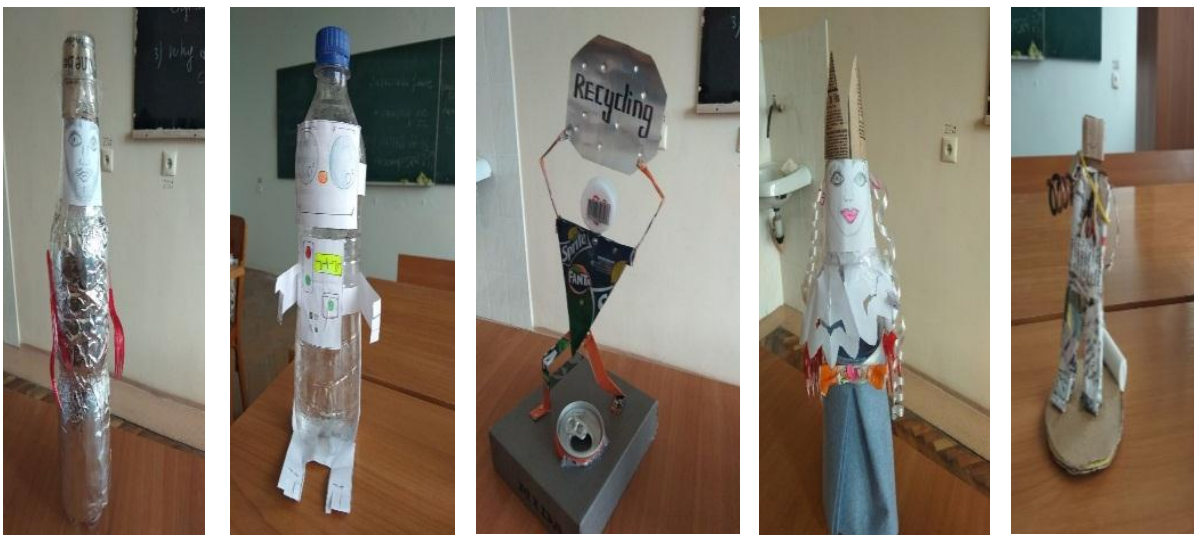

Fig. 1. Works of students of Igor Sikorsky KPI

What is the real process of making a robot? What are the common stages? What are the types of robots? Use the Internet to find more information about it. Prepare short theses and retell your partner the information you got. Imagine that your recycled robot is a real one. In pairs speak about its type and functions.

b) What are the ecological (or environmental) issues worldwide? Can robots help ecology (or help the environment)? If yes, then how? What do you think of a robot in the tree which pecks at it just like a real woodpecker to scare away destructive bugs? Or virtual reality headset for chickens due to which they get more space and feel happier? Visit Robotanica 2017 exhibition online site to see these and other robots! Work in pairs and discuss your opinion about them.

c) Work in pairs to think of an idea of a robot that can help the environment. Explain their tasks. Each pair should choose one best idea to present to the class. The winning pair is the one which gets most of the votes of the students.

d) Watch an English video about A famous robot Sofia. The robot has 72 facial emotions and obtained a citizenship of Saudi Arabia. Exchange your opinion about this robot and artificial intelligence in pairs.

e) Look at your recycled robot again! What is the problem of waste materials? Does it influence your health? Visit a Recycled Materials Museum in your city or a web site of a recycling program (for example, Call2Recycle). Choose one particular item exhibited and write how it affects the environment?

Task 3. Health and safety at work

Aim: Understanding ergonomics issues.

Creative skills: Artistry, personal expression,critical and creative thinking, imagination skills.

ESP skills: Listening, speaking, reading, writing about ergonomics issues, workspace, health, safety precautions.

Functional language: Researching, comparing, reasoning, analysing. 


\section{Instructions}

a) Look at our workplace. What can you say about its ventilation, temperature, lighting, cleanliness, dimensions, seating, safety? Find these norms from The Workplace Health, Safety and Welfare Regulations handout. Choose the parameter you can measure with the help of the formulas given. Compare the result with the norm.

b) Work in groups to make as many words as possible from the letters in S-a-f-e-t-y m-e-a-s-u-r-e-s. The group with the biggest number of accurate words wins!

c) Use the Workspace planner tool online which will help you to place your equipment correctly to establish a proper posture and Workspace assessment tool to evaluate your current studying conditions.

d) Work in mini-groups to write a safety poem for an engineer. Start each line with a new letter of the phrase Safety precautions. You can include lab safety rules as well.

e) Work in pairs. Tell your partner about the best office you have been to or the office of your dreams. What a video Exclusive Look Inside Facebook's Engineering Office (December 2019). What information do you find to be the most interesting/inspiring/unusual? What part of the office would you most often use?

f) Interview an engineer about his favorite place in the office, working conditions, design of the office.

Task 4. Engineering jobs

Aim: Understanding engineering career, branches of engineering, key inventions.

Creative skills: Artistry, personal expression, critical and creative thinking, imagination skills.

ESP skills: Listening, speaking, reading, writing about in-demand engineering jobs, most successful companies, CV of an engineer.

Functional language: Researching, comparing, reasoning, analysing.

Instructions

a) What positions of engineers are most demanding in your country and abroad? Compare your answers with the Most In-Demand Engineering Jobsfor 2019. In your opinion which of them will be in-demand in ten years? Why do you think so?

b) Check the official site of the ABB company. Where can you find information about engineering positions there? What career path among the suggested online would you choose? Work in pairs. Look at the Board of Directors page. Choose one of the executives to see his/her CV. Scan it and discuss the career growth, the structure of the resume.

c) Find an English CV of an engineer which attracted your attention. What information would you add or omit, discuss whether the best engineers are born or made, the basic things for success in your opinion.

d) Do you know any successful engineering companies? What do they produce? Google to get more ideas. In pairs think of your own engineering company; its name and slogan. Make a video advertising your company. Show it to the bank workers and answer their questions concerning the branch of engineering, the type 
of product you are offering; the kind of premises you need; the equipment you need, the amount of money you would like to offer. The winner is the pairthat gets the bank loan.

e) You are a famous engineer who wants to win the Best World Engineering Competition and get much investment for future investigations. Get a role card with the name of the greatest engineers of all time, his/her key biography facts and inventions. Remember this information, talk to each member of the group, tell about yourself, persuade others that you deserve winning. The winner is the person who gets the biggest number of votes in his/her support after talking.

\section{Task 5. Engineering education}

Aim: Understandingthe importance of education.

Creative skills: Artistry, personal expression,critical and creative thinking, imagination skills.

ESP skills: Listening, speaking, reading, writing university campus, inventions, engineering education.

Functional language: Organizing data,researching, comparing, reasoning, analysing.

\section{Instructions}

a) Group A: Watch the Engineering campus virtual tour of Illinois College of Engineering

Group B: Watch Harvard College virtual tour

Open $3 \mathrm{~d}$ online tour of your university. What is similar and what is different between the campuses. What art objects and spaces are described? What would you like to change on your campus?

b) Work in mini-groups. Choose three art objects of your university (for example, painting, architecture, exhibited technique, art space). Mark it on the e-map of your university. Justify your choice. Deliver a short story about its significance, history, materials or resources used, including numerical information if possible.

c) In your mini-group prepare a 15-question quiz about famous scientists who studied or worked in your university and their inventions. Deliver it to students from other groups. Take the quiz of the other group and vote for the most interesting question.

d) Look at the World University rankings 2018 by subject: engineering and technology. What are the top universities in the world/in the USA/ Canada/in Europe? What performance indicators are included? Do you agree that engineering universities should get a higher score for innovation and a lower for citations? Why? Would you like to work as a lecture or scientist at your university after graduation? Why?

e) Do you know about academic mobility programs at your university? Do you have any engineering experience abroad? Would you like to have? Work in mini-groups. Open information in English about one of the events of The Fulbright program in your country or ERASMUS which is accessible at the academic mobility department of your university. In pairs discuss requirements for participants, your potential participation, pros and cons of the program. 
$85 \%$ of Ukrainian students noted in the anonymous questionnaires that the approach is motivating, $83 \%$ confirmed improvement of their language skills, and $97 \%$ agreed that the tasks foster important skills of the 21 st century such as media, safety and environmental literacy, cooperation skills and others. Noteworthy that $20 \%$ of the students at first felt skeptical of doing some art. Some students claimed that art activities were time-consuming. The majority of students noted that the experience was unusual and memorable.

General observation allowed us to notice language improvement of the students of the experimental group. They developed their digital, collaboration, creative skills, became more engaged in the learning process.

\section{Discussion}

First of all, the tasks can be effective in a creative atmosphere where errors are not emphasised, the process and cooperation are important, creativity is recognised. For better results, scaffolding should be used to help students to become more independent. Instructions which stimulate high order thinking skills and unusual disciplinary connections are also crucial.

In the process of development of tasks with art elements for teaching engineers, the issue of time management becomes important. For example, at Igor Sikorsky KPI students of all courses have only one 90-minute practical lesson per week. In Pakistan, 120 minutes per week. In this situation some parts can be assigned as homework. For example, creating robot part from Task 2.

Another problem is that some future engineers are not used to doing creative tasks. This is why teachers should explain that art is used to understand the content better and remember it for longer. Art elements also can help to delve deeper into serious discussions. For example, making robots from recycling materials may at first seem to be just a joyful experience. However, when the robots are done and put in front of the class, and the teacher stimulates the discussion of material properties, asks about the period of decomposition, ways to reduce pollution, everybody understands that interlinking of art and engineering here leads to important communication practices.

The framework of the tasks comprises language (reading, speaking, writing, listening), relevant to professional goals content (for example, ecological issues in Task 2), skills (problem-solving, critical and creative thinking, reasoning, imagination, artistry, environmental literacy, health literacy, personal expression, collaboration, leadership and responsibility). Thus, the offered tasks help students to develop the 21 st century skills.

One more important thing concerning the STEAM tasks is that they can reduce the level of anxiety as they offer a lot of work in mini groups or pairs. As a result, collaboration skills of students can be enhanced. It is very important as most tasks in traditional Ukrainian and Pakistani engineering education are designed for individual work.

English language is an official language in Pakistan and is considered to be main language within institution. ESP teaching in Pakistan is still in its infancy. It is worth 
for engineering university to develop an ESP syllabus in order to solve language teaching and language learning problems. The first step to develop ESP syllabus is to do a need analysis (NA) of the language of the students. Need analysis relates to areas of practicalities and constraints, teaching methods, learning strategies, and material selections and relating to engineering students in Pakistan should be established in order to meet the present and future needs of the students in engineering programs [29]. According to our observations the undergraduates have difficulties with most language skills and sub-skills. Thus, the ESP program should be changed to improve the course.

The majority of teachers use lectures for teaching English courses in Pakistan. Most of the students responded that teachers of English courses used Power Point presentation for teaching. During classroom observation, the researcher found that contrary to the data provided by the students, none of the teachers used multimedia for teaching [30]. In this situation the tasks can be of great help as they foster multimedia usage in the ESP classroom. It is especially important in the case of limited educational facilities in Ukraine and Pakistan. However, most students in Ukraine and Pakistan have unlimitied Internet access on their mobile phones which is beneficially towards the completion of the Tasks.

All created tasks integrate a lot of native language materials specially chosen for engineers taking into account their needs. For example, online recycling programs, virtual tours of universities for engineers, information about mobility programs. Native materials positively influence language aquision, students get used to searching information in foreign language and professional content of the materials. And as a result, their media literacy increases, digital skills develop.

\section{Conclusion}

Current changes in the engineering caused by disciplinary collaborations and increasing demand for creativity lead to the necessity of STEAM application in the ESP classroom. For this purpose, special tasks with integrated art elements were created. Art elements are used to engage, motivate and develop creativity. All of the tasks are interdisciplinary, aimed at developing creative and language skills as well as other important skills of the 21 st century.

To use the tasks effectively teachers should consider time management, use scaffolding, stimulate creation of a creative environment and cooperation, recognise creativity and be creative themselves.

The integration of multi disciplines and art elements in education is still a new concept in teaching but the STEAM approach requires a lot of the teachers' preparation, experience, and creativity. STEAM can be successfully integrated into foreign language learning if teachers consider age, foreign language proficiency level, needs, and interests of the students, the level of their professional knowledge, their values as well as other psychological peculiarities. 
In the future, more research must be done to better study the influence of the STEAM approach on engineering creativity including making new interdisciplinary links.

\section{$7 \quad$ References}

[1] M. Grismer, "Evaluating the degree of stem curriculum incorporation in the elementary classroom", University of Iowa Honors Theses, 5, 2017. Accessed on: Sep. 10, 2019. [Online]. Available: https://ir.uiowa.edu/cgi/viewcontent.cgi?article $=1115 \&$ context $=$ hon ors_theses

[2] M. McDermott, The ASSIST Approach Handbook (Unpublished handbook). University of Iowa, Iowa City, 2017.

[3] A. Zollman, "Learning for STEM literacy: STEM literacy for learning", School Science and Mathematics, 112(1), pp. 12-19, 2012. Accessed on: Sep. 10, 2019. [Online]. Available: https://doi.org/10.1111/j.1949-8594.2012.00101.x

[4] J. S. Baron, et al., "Synthesis Centers as Critical Research Infrastructure", BioScience, 67(8). Accessed on: Sep. 10, 2019. [Online]. Available: DOI: 10.1093/biosci/bix053

[5] J. Hu and Y. Zhang, "Discovering the interdisciplinary nature of big data research through social network analysis and visualization", Scientometrics, 112(1), pp. 91-109, 2017. Accessed on: Sep. 10, 2019. [Online]. Available: https://doi.org/10.1007/s11192-017-2383-1.

[6] R. Morgan, and C. Kirby, "The UK STEM Education Landscape. Royal academy of Engineering", 2016. Accessed on: Sep. 10, 2019. [Online]. Available: https://www.raeng. org.uk/publications/reports/uk-stem-education-landscape

[7] V. A. Segarra, et al., "STEAM: Using the Arts to Train Well-Rounded and Creative Scientists", Journal Microbiology and Biology Education, 19(1), 2018. Accessed on: Sep. 10, 2019. [Online]. Available: https://doi.org/10.1128/jmbe.v19i1.1360

[8] M. G. Khanaposhtani, J. Liu, B.Gottesman and B. Pijanowski, "Evidence that an informal environmental summer camp can contribute to the construction of the conceptual understanding and situational interest of STEM in middle-school youth", International Journal of Science Education, Part B, 8, pp. 227-249, 2018. Accessed on: Sep. 10, 2019. [Online]. Available: https://doi.org/10.1080/21548455.2018.1451665

[9] P. Lowe, J. Phillipson and K. Wilkinson, "Why social scientists should engage with natural scientists", Contemporary Social Science: Journal of the Academy of Social Sciences, 8(3), pp. 207-222, 2013. Accessed on: Sep. 10, 2019. [Online]. Available: https://doi.org $\underline{10.1080 / 21582041.2013 .769617}$

[10] K. Osman, L. C. Hiong and R. Vebrianto, "21st Century biology: An interdisciplinary approach of biology, technology, engineering and mathematics education", Procedia - Social and Behavioral Sciences, 102, pp. 188-194, 2013. Accessed on: Sep. 10, 2019. [Online]. Available: https://doi.org/10.1016/j.sbspro.2013.10.732

[11] G. A. Boy, "From STEM to STEAM: Toward a human-centred education", Paper presented at the European Conference on Cognitive Ergonomics, Toulouse, France, pp. 1-8, 2013. Accessed on: Sep. 10, 2019. [Online]. Available: http://ntrs.nasa.gov/search.jsp?print=yes $\& \mathrm{R}=20130011666$

[12] P. C. Taylor, "Enriching STEM with the arts to better prepare 21st century citizens", AIP Conference Proceedings 1923, 020002, 2018. Accessed on: Sep. 10, 2019. [Online]. Available: https://doi.org/10.1063/1.5019491

[13] G. Yakman, "STEAM education: An overview of creating a model of integrative education”, Presented at the Pupils' Attitudes Towards Technology (PATT-19) Conference: Re- 
search on Technology, Innovation, Design \& Engineering Teaching. Salt Lake City, Utah, USA, 2008. Accessed on: Sep. 10, 2019. [Online]. Available: https://www.researchgate.net/publication/327351326_STEAM_Education_an_overvie W_of_creating_a_model_of_integrative_education

[14] J. V. Heilig, H. Cole and A. Aguilar, "From Dewey to No Child Left Behind: The evolution and devolution of public arts education", Arts Education Policy Review, 111(4), pp. 136-145, 2010. Accessed on: Sep. 10, 2019. [Online]. Available: https://doi.org/10.1080/ 10632913.2010 .490776

[15] F. R. Sabol, "Seismic Shifts in the Education Landscape: What Do They Mean for Arts Education and Arts Education Policy?", Arts Education Policy Review, 114(1), pp. 33-45, 2013. Accessed on: Sep. 10, 2019. [Online]. Available: https://doi.org/10.1080/10632913. $\underline{2013.744250}$

[16] M. K. Daugherty, "The prospect of an "A" in STEM education", Journal of STEM Education: Innovations and Research, 14 (2), 10-15, 2013.

[17] D. Henriksen, "Full STEAM ahead: Creativity in excellent STEM teaching practices", The STEAM Journal, 1(2), 2014. Accessed on: Sep. 10, 2019. [Online]. Available: https://doi.org/10.5642/steam.20140102.15

[18] C. F. Quigley and D. Herro, "Finding the joy in the unknown: Implementation of STEAM teaching practices in middle school science and math classrooms", Journal of Science Education and Technology, 25 (3), pp. 410-426, 2016. https://doi.org/10.1007/s10956-0169602-z

[19] J. H. Rolling, "Reinventing the STEAM engine for art + design education", Art Education, 69 (4), pp. 4-7, 2016. Accessed on: Sep. 10, 2019. [Online]. Available: https://doi. org/10.1080/00043125.2016.1176848

[20] G. Yakman, and H. Lee, "Exploring the Exemplary STEAM Education in the U.S. as a Practical Educational Framework for Korea", Journal of The Korean Association for Science Education, 32(6), pp. 1072-1086, 2012. Accessed on: Sep. 10, 2019. [Online]. Available: https://doi.org/10.14697/jkase.2012.32.6.1072

[21] T. Hadinugrahaningsih, Y. Rahmawati and A. Ridwan, "Developing 21st century skills in chemistry classrooms: Opportunities and challenges of STEAM integration", AIP Conference Proceedings 1868, 2017. Accessed on: Sep. 10, 2019. [Online]. Available: https://doi. org/10.1063/1.4995107

[22] B. Allina, "The development of STEAM educational policy to promote student creativity and social empowerment", Arts Education Policy Review, 119 (2), pp. 77-87, 2017. Accessed on: Sep. 10, 2019. [Online]. Available: https://doi.org/10.1080/10632913.2017. $\underline{1296392}$

[23] A. M. Connor, S. Karmokar and C. Whittington, "From STEM to STEAM: Strategies for enhancing engineering \& technology education", International Journal of Engineering Pedagogy, 5(2), pp. 37-47, 2015. Accessed on: Sep. 10, 2019. [Online]. Available: https://doi.org/10.3991/ijep.v5i2.4458

[24] N. W. Sochacka, K. W. Guyotte and J. Walther, "Learning together: A collaborative autoethnographic exploration of STEAM (STEM+ the Arts) education", Journal of Engineering Education, 105 (1), pp. 15-42, 2016. Accessed on: Sep. 10, 2019. [Online]. Available: https://doi.org/10.1002/jee.20112

[25] C. W. Thurley, "Infusing the Arts into Science and the Sciences into the Arts: An Argument for Interdisciplinary STEAM in Higher Education Pathways", The STEAM Journal, 2(2), 2016. Accessed on: Sep. 10, 2019. [Online]. Available: https://doi.org/10.5642/steam. $\underline{20160202.18}$ 
[26] Create to communicate. Office of English Language Programs. Bureau of Educational and Cultural Affairs. United States: Department of State Washington, D.C, 2013.

[27] N. Saienko, "Cognitive development of students in foreign language acquisition", Advanced Education, 7, pp. 4-8, 2017. Accessed on: Sep. 10, 2019. [Online]. Available: https://doi.org/10.20535/2410-8286.77570

[28] D. Pollard and Yu. Olizko, "Art and ESP integration in teaching Ukrainian engineers", Advanced Education, 11, pp. 68-75, 2019. Accessed on: Sep. 10, 2019. [Online]. Available: https://doi.org/10.20535/2410-8286.147539

[29] A. M. Channa, S. Soranastaporn, S. K. Engchuan and Y. Tirataradol, "A study of needs, problems and wants of using English of Engineering students at Quaid-e-Awam university of Engineering", Science and Technology, Pakistan. Journal of Education and Practice, 4(3), pp. 18-26, 2013.

[30] A. Sultan, A. Afsar, and S. Abbas, "Needs analysis: English courses for bachelors of engineering in Pakistan”, Journal of Educational Sciences \& Research, 6(1), pp. 1-18, 2019.

\section{Authors}

Nataliia Saienko is a Professor, Dean of the Faculty of Linguistics, National Technical University of Ukraine "Igor Sikorsky Kyiv Polytechnic Institute", E-mail: saenko106@gmail.com Her research interests relate to Psycholinguistics. ORCID 00000001-8898-5198

Yuliia Olizko is an Assistant Professor, The Department of English for Engineering № 1, National Technical University of Ukraine "Igor Sikorsky Kyiv Polytechnic Institute”, E-mail: juliukrainekyiv@gmail.com She is interested in art and ESP intergration in a foreign language classroom. ORCID 0000-0003-3473-9324

Muhammad Arshad is a PhD Scholar, Department of Education, The University of Lahore, Lahore-Punjab, Pakistan, E-mail: marshadzakki@gmail.com He is currently working as Science teacher in School Education Department, Pakpattan, PunjabPakistan. ORCID 0000-0003-2030-6851

Article submitted 2019-09-04. Resubmitted 2019-10-23. Final acceptance 2019-11-01. Final version published as submitted by the authors. 